Jurnal Penelitian dan Pengabdian Kepada Masyarakat Bidang ilmu Pendidikan

\title{
Upaya Meningkatan Kemampuan Menulis Puisi Siswa Kelas VII dengan Model Discovery Learning di SMP Negeri 1 Winongan
}

\author{
1) Farida Rochmawati, 2) Fatih Holis Ahnaf \\ Dosen Tadris Bahasa Indonesia, Universitas Islam Zainul Hasan Genggong \\ E-mail:faridarochmawati3@gmail.com
}

Article History: Received: 2021-01-05 || Revised: 2021-02-15 || Published: 2021-03-02

Sejarah Artikel : Diterima: 2021-01-05 || Direvisi: 2021-02-15 || Dipublikasi: 2021-03-02

\begin{abstract}
Language as a meaning system expressed in social systems has various forms according to the different purposes of using language in communication. To implement these learning objectives, language is used and learned in real terms in communication. Therefore the discovery learning model is a model that can be used to write poetry concerning natural beauty. In this research, the problem was whether the discovery learning model can help the students to improve their abilities and can motivate the students to write poetry regarding natural beauty. The goal to be achieved is to determine the level of student success in writing poetry regarding natural beauty and to determine the level of student enjoyment in learning. The research method was carried out directly through observation at SMP Negeri 1 Winongan, Pasuruan Regency in seventh grade students in the second semester of the 2018-2019 academic years. This research was conducted in 2 cycles divided into 2 meetings using test sheets to capture students' success in writing poetry related to natural beauty. The results of the study concluded that the discovery learning model can improve students' ability and motivate them to write poetry regarding natural beauty. This can be seen from the results of the first cycle of graders obtained were $72.92 \%$ and $65.85 \%$ to be $86.49 \%$ and $92.68 \%$, which means there was an increase of $13.57 \%$ and $26.83 \%$. This is a form of increasing the ability and motivation in writing poetry regarding the beauty of nature in seventh grade students of SMP Negeri 1 Winongan, Pasuruan Regency.
\end{abstract}

Keywords: Writing, Natural Beauty Poetry, Methods, Discovery Learning

\begin{abstract}
Abstrak
Bahasa sebagai sebuah system makna yang diekspresikan dalam system social memiliki berbagai bentuk sesuai dengan perbedaan tujuan penggunaan bahasa dalam komunikasi. Untuk mengimplementasikan tujuan pembelajaran tersebut bahasa digunakan dan dipelajari secara nyata dalam komunikasi. Karena itu model discovery learning merupakan salah satu model yang dapat digunakan untuk menulis puisi berkenaan dengan keindahan alam. Dalam penelitian ini yang menjadi permasalahan adalah apakah model discovery learning dapat membantu siswa dalam keningkatkan kemampuan dan dapat memotivasi siswa untuk menulis puisi berkenaan dengan keindahan alam. Tujuan yang ingin dicapai adalah untuk mengetahui tingkat keberhasilan siswa dalam menulis puisi berkenaan dengan keindahan alam dan mengetahui tingkat kesenangan siswa untuk belajar. Adapun metode penelitian dilakukan secara langsung melalui observasi di SMP Negeri 1 Winongan Kabupaten Pasuruan pada siswa kelas 7e semester genap tahun pelajaran 2018-2019. Penelitian ini dilakukan dalam 2 siklus terbagi dala 2 kali pertemuan dengan menggunakan lembar tes untuk menjaring keberhasilan siswa dalam menilis puisi yang berkenaan dengan keindahan alam. Hasil penelitian yang dapat disimpulkan bahwa model discovery learning dapat meningkatkan kemampuan siswa dalam menulis puisi berkenaan dengan keindahan alam serta dapat memotivasinya. Hal ini dapat dilihat dari hasil siklus pertama perata yang didapat adalah $72,92 \%$ dan $65,85 \%$ manjadi $86,49 \%$ dan $92,68 \%$ berarti ada kenaikan $13,57 \%$ dan $26,83 \%$. Inilah wujud peningkatan kemampuan dan motivasi dalam menulis puisi berkenaan dengan keindahan alam pada siswa kelas 7e SMP Negeri 1 Winongan, Pasuruan.
\end{abstract}

Kata kunci: Menulis, Puisi Keindahan alam, Metode, Discovery Learning

\section{PENDAHULUAN}

Pelajaran Bahasa Indonesia mempunyai banyak kompetensi yang harus diajarkan. Termasuk juga materi kebahasaan dan kesastraan. Semua terangkum dalam kompetensi dasar yang sudah ditetapkan dalam kurikulumnya. Kompetensi itu menjadi dasar bagi guru untuk menentukan target 
ketercapaian pelajaran yang dilaksanan. Dengan demikian setiap kompetensi memilik tingkat kesulitan dan pepentingan sendiri. Dalam kompetensi dasar yang mengacu pada materi kebahasaan dapat dirangkai dengan materi kesastraan dalam proses pelaksaannya. Namun bisa juga terpisah karena banyak hal. Media bahasa akan diperlukan dalam semua hal. Untuk itulah bahasa dapat dipelajari oleh semua orang. Manusia dalam berkomunikasi membutuhkan bahasa. Untuk itulah kedudukan bahasa menjadi sangat penting untuk diajarkan di sekolah terutama tingkat SMP. Di tingkat ini siswa akan dilatih untuk menguasai kemahiran berbahasa yang disesuaikan dengan tingkatan usianya untuk mempersiapkan diri dalam menjalani kegiatannya sekarang maupun yang akan datang. Kemampuan berbahasa akan sangat diperlukan, sehingga dalam sekolahpun sangat perlu untuk mendapatkan perhatian.

Salah satu kompetensi dasar dalam pelajaran bahasa Indonesia adalah adalah menulis puisi berkenaan dengan keindahan alam. Banyak siswa yang menganggap menulis puisi itu mudah karena mereka telah memahami betul . Ada juga yang asal-asalan karena ada dalam pelajaran di sekolah khususnya pelajaran Bahasa Indonesia. Tapi banyak juga yang belum mengenal dan memahami puisi itu sendiri karena belum pernah mendengarnya karena banyak alas an. Pada kompetensi yang diharapkan untuk kelas tujuh ini dimunculkan materi tentang menulis puisi yang nerkenaan dengan keindahan alam. Karena alasan tersebut, peneliti beranggapan bahwa kelas yang diambil peneliti untuk dilaksanakan penelitian ini termasuk kategori kelas yang belum mampu memahami puisi yang berkenaan dengan keindahan alam, maka kelas ini dipilih untuk dijadikan subyek penelitian. Hal itu dimaksudkan untuk memberikan masukan dan peningkatan yang dapat dilakukan oleh siswa maupun guru dalam kegiatan pembelajaran.Guru dapat mencari berbagai cara untuk membelajarkan siswa tentang materi puisi yang berkenaan dengan keindahan alam. Dan siswa pun dapat belajar dengan lebih nyaman tanpa terbebani rasa yang sulit tentang menulis puisi. Karena kata-kata dalam puisi banyak dipengaruhi oleh pilihan kata dan persamaan kata di akhir suku katanya, maka sering kali dirasakan bahwa menulis puisi itu lebih rumit. Ini hanya menyangkut kebiasaan dan kecermatan dalam mengolah kata.

Berdasarkan hal-hal yang sudah disebutkan diatas, dapat membantu siswa dalam menyusun puisi yang akan dipelajari di sekolah sehingga dapat mencapai tahapan penilaian yang diharapkan, yaitu sesuai dengan KKM. Adapun tujuan dari penelitian ini adalah untuk meningkatkan kemampuan siswa dalam menulis puisi yang berkenaan dengan keindahan alam dengan mencari obyek kata yang sesuai dengan gambar yang ditampilkan. Dari kegiatan mengamati gambar ini diharapkan siswa akan tahu dengan sendirinya bahwa kalimat yang seharusnya digunakan dalam puisi itu sesuai dengan hal yang telah dicontohkan. Dengan mengetaui contoh akan memudahkan siswa dalam memahami cirri-ciri dari sebuah puisi yang nantinya dapat dipergunakan untuk keperluannya sendiri dalam mengolah kata dalam menyusun puisi.

\section{A. Pembelajaran Menulis}

Pembelajaran bahasa (termasuk juga menulis) terpadu dilandasi oleh prinsip-prinsip sebagai berikut, pertama siswa adalah pembelajar yang konstruktif. Mereka terus-menerus berpikir tentang dunia mereka sebagai dasar apa yang dipelajari dan susun. Kedua, bahasa adalah sistem makna yang dikomunikasikan dalam kehidupan sosial. Karena bahasa digunakan untuk bermacam-macam tujuan, maka makna tersebut diekspresikan dengan cara yang bermacammacam. Bahasa tidak dapat dipahami, diintrepretasikan, dan dievaluasi tanpa dihubungkan dengan konteks social tempat bahasa itu digunakan, karena itu bahasa dipalajari melalui penggunaan actual. Pola-pola bahasa yang bervariasi dipelajari dalam penggunaan untuk berbagai tujuan dan konteks social. Ketiga, siswa pada dasarnya sudah memiliki pengetahuan. Pengetahuan itu diorganisasikan dan disusun melalui interaksi sosial. Pengetahuan itu secara tiba-tiba akan berubah dalam kehidupan mereka dan dibangun dengan representasi mental yang didasarkan atas perjalan individual. Selanjutnya, pengetahuan itu selalu dimodivikasi dan bersifat tentative sementara. Pengetahuan itu tidak statis dan absolute dalam menyikapi obyek. Karena siswa itu hidup dalam lingkunan social, maka mereka selalu menyikapi budaya yang ada di lingkungannya dan keadaan sosial yang selalu berubah serta peristiwa-peristiwa sejarah. (Pappas,dkk dalam Nurchasanah, 1994:35)

Aplikasi ketiga prinsip di atas dalam pembelajaran menulis, siswa perlu dihadapkan pada dunia nyata yang ada di lingkungan sosialnya. Mereka perlu dilatih untuk berinteraksi dengan 
lingkungan social mereka. Mereka perlu diberi kesempatan untuk berintegrasi dengan kehidupan nyata dengan bekal pengetahuan yang sudah mereka miliki. Dengan demikian, mereka akan dapat berpikir secara kreatif dan konstruktif. Dengan cara demikian, siswa diharapkan dapat menemukan hal yang akan ditulisnya dari lingkungan sosial mereka sendiri dan dapat mengembangkan hal tersebut serta menata bahan dengan kreatifitas mereka sendiri

\section{B. Prinsip Pembelajaran Menulis}

Tujuan pembelajaran menulis terpadu adalah agar siswa dapat mengkomunikasikan dalam bahasa tulis sesuai dengan konteks pemakaian bahasa yang wajar. Untuk mencapai tujuan itu, pembelajaran menulis bisa memadukan beberapa aspek pembelajaran bahasa, baik yang bersifat kebahasaan maupun kesastraan. Misalnya, keterampilan menulis dipadukan dengan menulis puisi, keterampilan menbaca dipadukan dengan pembelajaran berpidato, dan sebagainya. Keterpaduan ini tidak hanya berfokus pada aspek pembelajarannya, tetapi proses belajar mengajarnya bersifat juga bersifat terpadu. Di samping ketiga prinsip di atas, Semiawan,dkk (1992:10-13) juga mengemukakan beberapa prinsip dalam memotivasi pembelajaran, antara lain: (1) motivasi, (2) latar/konteks, (3) keterarahan pada titik fokus/pusat tertentu, (4) hubungan social/sosialisasi, (5) belajar sambil bekerja, (6) menemukan,dan (7) pemecahan masalah. Dari masing-masing prinsip itu diharapkan dapat membantu siswa memotivasi belajar lebih mendalam tentang suatu materi pelajaran. Di samping itu, juga dapat membantu guru untuk menciptakan kelas yang kondusif.

\section{Model Discovery Learning}

Model discovery learning adalah salah satu model pembelajaran yang berorientasi pada aktifitas siswa. Pada model ini sistem pembelajaran menempatkan siswa sebagai subyek belajar. Dalam hal ini menekankan pada aktifitas siswa secara optimal untuk memperoleh hasil belajar yang seimbang antara aspek kognitif, afektif, dan psikomotorik. Dengan kata lain, aktifitas siswa dalam pembelajaran tersebut tidak hanya aktifitas fisik saja tetapi juga aktifitas mental, intelektual, dan emosional, Mufida dalam Masnur Muslich (2009:33). Dalam buku panduan implementasi kurikulum 2013 disebutkan adanya langkahlangkah yang dapat diterapkan dalam model discovery learning sebagai berikut: a) tahap stimulation (pemberian rangsangan) yaitu membuat kondisi siswa untuk bertanya agar siswa lebih aktif untuk mengetahui apa yang akan dipelajari. b) tahap problem statement, (identifikasi masalah) yaitu kondisi dimana siswa mengumpulkan jawaban-jawabannya. c) tahap data collection (pengumpulan data) yaitu siswa dapat mencari bukti-bukti yang mendukung atas jawaban-jawaban yang telah dikumpulkannya. d) tahap data processing (pengolahan data) yaitu kegiatan siswa melalui kegiatan diskusi untuk menetapkan atau mengambil keputusan akan pembuktiannya. e) tahap verification (pembuktian) yaitu siswa mulai menemukan konsep-konsep yang relevan dengan apa yang telah ditemukan. f) tahap generalization (menarik kesimpulan) yaitu siswa bersama menarik kesimpulan atas apa yang telah mereka cari untuk dijadikan prinsip umum dan berlaku untuk semua kejadian yang sesuai dengan masalah yang telah dipecahkan.

Menurut Ghazali dalam Masnur Muslich (2002:122), pemilihan strategi belajar mengajar harus dilandaskan pertimbangan menempatkan siswa sebagai subyek belajar yang tidak hanya menerima secara pasif apa yang disampaikan oleh guru. Dalam pembelajaran menulis pantun yang merupakan salah satu bentuk puisi lama yang masih harus terikat dengan syarat-syaratnya dan tidak boleh ditolak karena sudah menjadi ketetapannya. Karena pantun merupakan salah satu bentuk puisi lama sehingga contoh-contoh yang ada juga menggunakan kosa kata lama yang kadang tidak dipahami oleh siswa di masa sekarang. Oleh karena itu, diusahakan siswa dapat menulis puisi yang berkenaan dengan keindahan alam dengan langkah-langkah yang ada dalam model discovery learning.

Berdasarkan konsep di atas akan dapat memberikan keuntungan bagi siswa untuk bisa menggunakan pilihan kata yang sesuai dalam penggunaannya menyusun sebuah puisi.

\section{Hipotesis Tindakan}

Hipotesis tindakan yang dapat digunakan dalam menyelesaikan masalah sebagai berikut: siswa yang merasa sulit untuk menyusun sebuat puisi,diberikan contoh-contoh gambar 
pemandangan alam dan kata-kata yang dapat ditarik dari gambar tersebut. Setelah menemukan kata yang sesuai/cocok dengan gambar yang ada, barulah dibuat lariklarik/kalimat kemudian dirangkaikan menjadi sebuah puisi.

\section{METODE PENELITIAN}

\section{A. Setting Penelitian}

Penelitian ini dilaksanakan di SMP Negeri 1 Winongan Kabupaten Pasuruan Propinsi Jawa Timur. Jumlah kelas paralel 21 kelas dengan jumlah siswa 36-40 per kelas. Bahasa yang dipakai antara lain bahasa ibu $10 \%$ bahasa Madura, dan $90 \%$ bahasa jawa. Keadaan ekonomi orang tua siswa $50 \%$ karyawan, $20 \%$ pegawai, $30 \%$ petani dan pedagang.

\section{B. Persiapan penelitian}

Dalam pelaksanaan penelitian diperlukan perangkat KBM seperti, Kurikulum KTSP, Prota, Promes, Silabus, RPP, Buku Paket dan Penunjang, LKS, dan media pembelajaran. Persiapan penelitian antara lain (a) penentuan sampling kelas penelitian, (b) penyusunan jadwal penelitian, (c) penyusunan instrument untuk menggali tentang aktifitas guru dalam KBM dan aktifitas siswa pada saat pelaksanaan penelitian, dan (d) penyusunan alat evaluasi.

\section{Siklus Penelitian}

Penelitian tindakan kelas ini dilaksanakan dalam 2 siklus terbagi menjadi 2 kali pertemuan. Setiap siklus terdiri dari 1 kali pertemuan. Persiapan perencanaan dilakukan di luar KBM. Hasil siklus pertama ternyata masih belum memenuhi standar ketuntasan minimal yang telah ditentukan yaitu $80 \%$ ketuntasan secara klasikal. Karena masih ada hasil tes di bawah standar yang ditetapkan. Berdasakan hasil refleksi yang dilakukan oleh peneliti dan pengamat,pada siklus pertama penguasaan kelas yang diteliti masih belum maksimal. Hal itu dikarenakan masih ada siswa yang belum bisa menjawab soal tes dengan tepat sehingga nilai/skor yang didapatkan kurang dari KKM. Dan bentuk kerjasama siswa yang kurang maksimal(masih ada siswa yang tidak dapat bekerja sama). Untuk itu dilakukan siklus kedua dengan perencanaan pada persiapan KBM antara lain persiapan RPP, LKS, pembentukan kelompok yang lebih bervariasi. Dan dari refleksi pada siklus kedua terjadi peningkatan dan memenuhi standar ketuntasan yang diharapkan.

\section{Instrumen penelitian (Instrumen non tes \& Lembar observasi)}

Instrumen ini digunakan untuk menjaring data kegiatan guru mengajar yang digunakan untuk refleksi. Observasi ini berisi komponen kegiatan guru dalam proses belajar mengajar mulai dari pendahuluan sampai penutup. Hasilnya berupa data kuantitatif dan kualitatif

\section{E. Lembar angket siswa}

Instrumen ini digunakan untuk menjaring data pendukung kegiatan guru mengajar yang ditunjukkan oleh antusias atau motivasi siswa dalam mengikuti pembelajaran menulis puisi yang berkenaan dengan keindahan alam yang hasilnya berupa data kualitatif.

\section{F. Catatan Lapangan}

Instrumen ini digunakan untuk menjaring data pendukung kegiatan mengajar guru yang berupa temuan-temuan selama guru melaksanakan KBM yang hasilnya berupa data kualitatif. Data ini digunakan untuk refleksi atau revisi pada siklus berikutnya.

\section{G. Lembar tes}

Instrumen ini digunakan untuk menjaring data keberhasilan siswa dalam mengikuti kegiatan pembelajaran menulis puisi yang berkenaan dengan keindahan alam yang berupa dokumen pekerjaan siswa. Dokumen ini dianalisis menggunakan table penilaian.

\section{H. Teknik Pemantauan}

Teknik pemantauan pada penelitian tindakan kelas ini menggunakan teknik observasi langsung di dalam kelas pada saat KBM. Menggunakan lembar observasi. Sedangkan hasil 
belajar siswa dipantau dengan menggunakan instrument yang akan menghasilkan data berupa dokumen pekaerjaan siswa.

\section{HASIL DAN PEMBAHASAN}

Berdasarkan hasil tes siswa pada siklus pertama dan kedua tentang kesesuaian menulis puisi yang berkenaan dengan keindahan alam dengan model discovery learning dapat diperoleh nilai rata-rata yang dihasilkan sebagai berikut:

Tabel 1. Hasil tes siswa pada masing-masing siklus

\begin{tabular}{|l|l|l|c|l|}
\hline \multirow{2}{*}{ Kelas } & Obyek Penelitian & \multicolumn{2}{|c|}{ Nilai Rata-Rata } & \multirow{2}{*}{ Responden } \\
\cline { 3 - 4 } & & Siklus I & Siklus II & \\
\hline $7 \mathrm{e}$ & Hasil tes pengetahuan & $72,92 \%$ & $86,49 \%$ & 37 siswa \\
& Hasil motivasi siswa & $65,85 \%$ & $92,68 \%$ & 37 siswa \\
\hline
\end{tabular}

Pada siklus I, jumlah siswa yang mencapai nilai di atas kkm meningkat dari kondisi nilai awal, yaitu dari 21 anak yang mencapai nilai kkm menjadi 27 anak yang mendapat nilai di atas kkm. Hal ini menunjukkan adanya kenaikan nilai yang dicapai oleh anak. Sedangkan Pada siklus II, juga terjadi kenaikan. Dari siswa yang mendapatkan nilai di atas KKM menjadi 32 siswa. Hal ini terjadi kenaikan 13,57\% dari siklus I.

\section{SIMPULAN DAN SARAN}

\section{A. Simpulan}

Dari pelaksanaan penelitian tindakan kelas ini dapat disimpulkan bahwa dengan menggunakan model discovery learning dapat meningkatkan kemampuan dan motivasi siswa dalam menulis puisi yang berkenaan dengan keindahan alam. Hal ini dapat dilihat dari kenaikan hasil belajar dan motivasi kesenangan belajar siswa terhadap pelajaran menulis puisi yang berkenaan dengan keindahan alam yang diteliti pada siklus I peratanya $72,92 \%$ dan $65,85 \%$ menjadi $86,49 \%$ dan $92,68 \%$ pada siklus kedua. Itu berarti ada peningkatan hasil sebesar $13,57 \%$ dan 26,83\%. Melihat peningkatan data di atas bahwa model discovery learning dapat digunakan sebagai model pembelajaran menulis puisi yang berkenaan dengan keindahan alam dengan menarik dan dapat meningkatkan motivasi belajar siswa.

\section{B. Saran}

Berdasarkan hasil penelitian, dapat diketahui bahwa penerapan menulis puisi berkenaan dengan keindahan alam dapat mendukung tercapainya tujuan pembelajaran keterampilan menulis. Dengan demikian, hasil penelitian ini layak dipertimbangkan untuk dijadikan sebagai bahan acuan bagi guru mata pelajaran Bahasa Indonesia pada SMP/sederajat dalam mengajarkan materi ketrampilan menulis, khususnya di SMP Negeri 1 Winongan Kabupaten Pasuruan.

\section{DAFTAR RUJUKAN}

Ahmad, Maskur. 2006. Kinesiologi Olahraga. Palembang : UNSRI

Arikunto, S. (2012). Prosedur Penelitian Suatu Pendekatan Praktek. Jakarta: Rineka Cipta.

Arsil. 2009. Pembinaan Kondisi Fisik. Padang: FIK UNP.

Fathirma'ruf, F., \& Said, M. B.(2020). Pengembangan Perangkat Pembelajaran Konstruktivistik Model Teaching with Analogies (TWA) pada Mata Kuliah Database Management System (DBMS) untuk Meningkatkan Kemampuan Berpikir Kreatif Mahasiwa. Jurnal Teknologi Informasi dan Ilmu Komputer, 7(5), 1051-1060.

Hay. 2008. The Biomechanic of Sport techniques. Amerika : United states of Amerika.

Irawadi, Hendri. 2014. Kondisi Fisik dan Pengukurannya. Padang: UNP Press. 
Khomsin. 2011. Atletik 1. Semarang : Unnes Press

Kurniawan, Feri. 2011. Buku Pintar Olahraga Mens Sana In Corpore Sano. Jak arta : Lask ar Aksara

Lukman. 2013. Biomekanika Penerapan Hukum-Hukum. dan Prinsip- Prinsip Mekanika. Surabaya : Unesa University Press

Maksum, A. 2012. Metodologi Penelitian dalam Olahraga. Surabaya : Unesa

Muhajir. 2013. Pendidikan Jasmani dan Kesehatan Olahraga. Jakarta : Yudistira

---,2014.Modul pelatihan implementasi kurikulum 2013. BPSDM kementrian pendidikan dan kebudayaan 